\title{
Strategies for Implementing Bureaucratic Ethics in Providing Business Permit Services at the Makassar City Integrated Licensing and Investment Board Office (BPTPM)
}

\author{
Andi Rasyid Pananrangi ${ }^{1}$, Nurkaidah ${ }^{1}$ \\ Email: ar.pananrangi@ universitasbosowa.ac.id \\ ${ }^{1}$ Public Administration Study Program, Postgraduate, University of Bosowa Makassar, South \\ Sulawesi, Indonesia
}

Received: July 23, 2021

Received in Revised: August 11, 2021

Accepted: September 19, 2021

\begin{abstract}
This study aims to analyze the Strategy of Applying Bureaucratic Ethics in Providing Business License Services at the Makassar City BPTPM Office. This research method uses a qualitative research approach. Primary data were obtained by researchers through in-depth interviews with informants, observations in the object of research, and document searches at the Makassar City BPTPM. The results showed that the strategy of implementing bureaucratic ethics in the provision of business license services in Makassar City with the results showing that the registration of business licenses with the online system was considered adequate and in terms of quality it was concluded that it was inadequate for the licensing service process. which is programmed by the government with what the community expects, and on time services in business license services, no apparatus shows adequate achievements. The strategy for implementing BPTPM bureaucratic ethics is expected to be able to respond quickly to people who need licensing management services.
\end{abstract}

\section{Keywords: Strategy, Bureaucratic Ethics, Licensing Services}

\section{Introduction}

The ethics of state administration lies between the branches of professional ethics and political ethics. The assumption used is that an administrator is a person who must apply management and organizational sciences professionally. He must be able to solve tactical problems well and be able to manage the organization efficiently. However, in contrast to positions in professions such as lawyers, doctors, pharmacists, or business managers, an administrator must be accountable to a much wider and diverse community. Therefore, he is also required to have a high sensitivity to political issues.

The dilemma that must be faced by administrators is not only how to make public organizations run efficiently, but also how to make these organizations able to provide services that satisfy the public. In a pluralist society, this kind of dilemma will obviously be more complicated. Meanwhile, as a person who has the authority to make decisions, he must be able to put decentralization in the organization properly. A profession that provides services to the community must have a code of ethics which is a set of moral principles and regulates professional behavior. Without ethics, the bureaucratic profession will not exist as a service provider for the community. Professional ethics of bureaucrats in Indonesia are regulated in the Indonesian Code of Ethics for Bureaucrats.

This fact is evidenced by the results of several studies, although they are still very small, at least the study of public service ethics shows that the ethical aspect is the dominant factor in shaping excellent service. A study conducted by Dwiyanto (2006) revealed that there was no change in bureaucratic culture and bureaucratic behavior in public services. Meanwhile, 
bureaucratic culture should be born from ethical considerations of bureaucrats. This study confirms that the position of ethics in public services will lay the foundation for the creation of a bureaucratic culture and bureaucratic behavior that is expected to create accountability and transparency to the public.

Another study found that ethics as the dominant element that affects the quality of public services. The emergence of a public service crisis indicated by Anwaruddin's research (2004) is indicated by the sluggishness of service and the high cost of service, arising because it is related to the ethics of public services by the government. The findings of this study indicate that basically public services provided to the community still contain values that are contrary to applicable norms and rules. The service process is slow, requires relatively longer time than it should be, the costs incurred are greater than it should be, making the service process far from its ethical value. Ideally, public services must prioritize the interests of the community, not based on the interests of the bureaucracy.

This condition of weak service ethics is expected to be avoided by fulfilling the agreed and shared ethical values and norms. The importance of upholding these values and norms, by Maani (2010) emphasizes that it can be realized in the form of fulfilling the values and norms of attitudes and behavior of the public bureaucracy in services and actions that can be accepted by the wider community. On this basis, ethics is needed in public administration. Ethics can be used as guidelines, references, instructions on what to do by the bureaucratic apparatus in carrying out political policies, and at the same time used as a standard for assessing whether the behavior of the bureaucratic apparatus in carrying out political policies can be said to be good or bad.

Based on the background of the problem, this research will focus on issues related to bureaucratic ethics in business licensing services in Makassar City, namely the Integrated Licensing and Investment Board (BPTPM). This research is expected to provide an overview of ethical services based on bureaucratic ethics in accordance with the ASN Law number 5 of 2014 regarding the attitude of bureaucrats in providing services at the Makassar City BPTPM

\section{Methods}

Research that leads to the analysis of bureaucratic ethics in public services at the Makassar City BPTPM office, using a qualitative research approach. Primary data were obtained by researchers through in-depth interviews with informants, observations in the object of research, and document searches at the Makassar City BPTPM. The strategy applied in the business license service is an effort made by the agency to improve services to the community which consists of: (a) Registration of business licenses with an online system is that the public is given information through electronic media to register for the issuance of business licenses, (b) Application service queuing system, namely providing equal opportunities to the community in providing services according to the work mechanism, and (c) On time service is the provision of services for issuing business licenses to maximize the use of time as effectively as possible. The analysis component of the phenomenological interactive model consists of collecting data, reducing data, presenting data and drawing conclusions.

\section{Results and Discussion}

\section{Registration of Business Licenses with the Online System}

As a form of the Government's seriousness in prioritizing the quality of government services to the community, the Government through the approval of the DPR RI stipulates the RI Law Number 14 of 2008 concerning Openness of Public Information, which is a condition that 
allows the growth of public participation in the implementation of the life of the nation and state, including in the administration of regional government.

It is also known that information is part of the communication process, where information is important in the framework of policy formulation as the assumption of Edward III (1980) explains that the communication factor is an important aspect of the success or failure of a policy. Meanwhile, Myers (2002) suggests that communication is the exchange of information and the delivery of meaning, which is essential for a social system or organization. Furthermore, Myers, (2002) emphasizes that communication occupies a central position in organizations, because of the organizational structure; organizational expansion; and the scope of the organization is determined by communication techniques. Communication scientists consider communication to be the dominant force in organizational life (Keyton, 2017). Both private and public organizations, communication is at the core of the organization. Without communication there will be no organizational activity. Therefore, communication is also seen as part of the organizational process.

If we evaluate the type of information obtained by the Makassar City BPTPM above, it can be concluded that the source of executive information is relatively low. In fact, if the executive wants adequate information, it can be accessed through academic studies with experts in their fields, but this is rarely done. This is in accordance with what was stated by Wahab (2021) that although the public provides quality information in large quantities, executive accountability remains low if executive actors are not interested or do not understand the substance of information from the community, it is difficult to utilize data and information properly. .

The government cannot close itself to the spotlight of various parties for everything that is happening in this area. This tendency is the result of the development of demands for the interests of humanity. The information network that used to be limited is now almost unlimited in scope. One of the pressing factors for Global Information Space (GIS) is the increasing human need for peace. In a limited sense of the restraint of freedom in the context of the globalization of communication, which will become more and more transparent over time. No longer can any regional leader, nor the people they lead, hide themselves.

In the midst of the application of information and communication globalization, elites will no longer be able to harass the voices of the people (Ugor \& Mawuko-Yevugah, 2016). It will also be impossible for the government and any society to continue to use an unfair or one-sided mode of communication.

Many people worry that industrialization will lead to fundamental changes in almost all aspects of life. Social transformation; political culture; economy; and security that occur simultaneously from the change from a traditional agrarian society to a modern society (Rose, 2015). Advances in technology drive industrialization that can shape the values of human dependence on technology. Humans and technology are like two sides of the same coin. On the other hand, humans control technology, while on the other hand, humans are controlled by technology.

If it is feared that industrialization will spur rapid social change, it makes sense. If it is assumed that industrialization will allow the growth and development of value shifts, that also makes sense. In such concerns, it is worth worrying that cultural and religious values will increasingly fade in the life of the nation and state. Because in industrial life, it is not impossible that the role of culture and religion in guiding the direction of human life will be increasingly narrowed. This is because industrial society tends to ignore dogmatic things. Everything will be believed to be credible, if it can be explained with a rational measure. 
The dominance of communication technology that gave birth to industrialization in the field of information, which will be able to damage the human mental structure than industrialization in other fields ( $\mathrm{Li}$ et al, 2017). Do not let economic forces and political engineering dominate the information and communication system. So that the desire to manage the Makassar City area independently in accordance with the spirit of autonomy based on Law number 32 of 2004 which has been amended by Law number 12 of 2008 concerning Regional Government, seems difficult to achieve.

Al Hasani, (2018) said that one of the drivers and includes government reform to realize Good Governance (especially in the implementation of regional autonomy) is the use of information technology in governance, services and development. With regard to information technology, especially network technology, since 2003 a management policy based on Electronic Governance (e-Gov) has been formulated or often referred to as Electronic Administration (eAdm).

Likewise, Said (2007) said that regions that want to improve the quality of their public services must dare to innovate by using communication technology so that public expectations of government performance will increase. Thus, the more advanced an area is, the higher the level of e-Gov applications in providing services to the public.

The dominance of technology and information and communication systems beyond the power of the people of Makassar City to filter news, will also damage the personality of the people of Makassar City. Convergent mental and personality structures as personality traits of the people of Makassar City are slowly changing the information system that has been dominated by outside forces to become heteronomous.

This is the threat of industrialization in the information sector, which is more worrying than the negative impact of industrialization in other fields. The role of communication experts is time to anticipate and predict the problem to ward off threats that will continue. If the Makassar City media does not function effectively in enforcing a communication system that breathes our eastern culture, it is difficult to imagine what will happen in the future. Therefore, local governments should be responsive to information from various parties related to the idea of anticipating the mobilization of information by parties who are disappointed in a destructive direction.

Although they have accessed various information relevant to the Makassar City BPTPM, but the information is not realized in the realisits policy process, it will not provide significant benefits. Therefore, the use of information in terms of service to the community needs special attention. The stagnation of the use of information on a policy is largely determined by the human resources of the BPTPM apparatus as policy makers and as policy implementers. In today's modern era, what is really needed is an executive element that can translate the essence of excellent service, and the best service can only be done by innovative executives.

Theoretically, matters related to excellent service are in line with what was expressed by Said (2007) that innovative culture, efficiency and effectiveness are the key criteria for government success. Meanwhile, Haq Muis (2016) emphasizes that to fulfill these duties and responsibilities, it must be supported by management that leads to public satisfaction in the aspect of timeliness of service.

Departing from the reality of the research results, it seems that it does not provide an example for the community in the Makassar City BPTPM process. Theoretically it should be applied in such a way, so that it can provide an example for licensing in Makassar City to realize representative and applicable services. Therefore, it is not surprising that understanding press behavior through normative theories often results in deep disappointment. Because the 
normative approach is more directed to idealistic constructions that are das solen, not das sein. So that the communication approach that is empirical by looking at the various components in it, feels it will be more directed to an administrative mechanism.

\section{Application of the Queue System for Business License Services}

The study of a service system to the public is a study of how to provide services to the community in this case services to those who are engaged in licensing carried out by the apparatus. As a system, the service provided is a totality that is built from elements that are related to one another so that it is a systematic orderly arrangement.

A service system can be said to be good or bad if it is able or unable to satisfy the community. This condition can be achieved if the community has formed an opinion based on their perception of the services that have been provided. The opinion that has been formed is an indication of the satisfaction or dissatisfaction given which is reflected in a number of measurements of several dimensions of the quality of business license services.

Based on the Mayor's Regulation Number 60 of 2015, that the objectives, principles, and scope of the Makassar City BPTPM carry out tasks with the following formulation: (a) Provide legal protection and certainty to the community, (b) Shorten the service process, (c) Realize the service process that is fast, easy, cheap, transparent, sure, and affordable, and (d) Bringing and providing broad services to the community.

The implementation of business license services by Makassar City BPTPM is carried out with the following principles: (a) Integration, (b) Economical, (c) Coordination, (d) Delegation or delegation of authority, (e) Accountability, and (f) Accessibility. Then the scope of the implementation of BPTPM includes all licensing and non-licensing services which are the authority of the Makassar City government. The implementation of BPTPM as referred to in Article 4 of Perwalkot Number 60 of 2015, is carried out by the City Government for licensing and non-licensing services from mandatory and optional affairs which are the affairs of the City Regional Government.

Meanwhile, the SKPD which is technically related to licensing services, is obliged and responsible for carrying out technical guidance and supervision of the permits that have been issued by the Makassar City BPTPM, in accordance with: (1) Technical studies on the types of licensing services are carried out by a technical team consisting of technical SKPDs. as a representative seconded to the Agency, (2) the Technical Team is required to provide technical considerations and submit it to the technical SKPD for further processing and the signing of recommendations is carried out by the technical SKPD, (3) The technical team as referred to in paragraph (1) is proposed by the head of BPTPM, and (4) The Technical Team as referred to in paragraph (3) is determined by a decision of the Mayor.

In a public service activity such as a business license service at the Makassar City BPTPM, there are several indicators that greatly affect the service. The indicators of this study were measured by the following predictors:

\section{Procedural}

Operationally, the procedure is a stage and requirement that must be passed by individuals from beginning to end in order to get a predetermined plan from a public service delivery (Deshapriya et al, 2017). Where the stages and requirements are determined by the organizers to ensure regularity and smoothness in an effort to serve the community so that the service process in question can run as it should. It can also be said that the procedure is a legal rule of an activity or work of an organizational unit that must be carried out, so that every work activity can run in an orderly and controlled manner. 
In addition, it can also be said that the procedure is a guideline for the community to prepare all things related to the expected service delivery. In turn, there will be harmony between the service providers and the community. It can also be understood that a service procedure is not only required to create order but is also required to provide convenience and clarity for people who need a service.

To be able to know and understand a stage or mechanism that must be passed as well as the requirements, and costs that must be incurred by the community in getting good service, clarity about service procedures is a key. This is very important for the community because the clarity of the procedure will make the public know for sure the things that must be done and prepared to obtain business license management services at the Makassar City BPTPM. The clarity of the procedure is very important for the community, this requires a clear work plan, so that the community knows for sure the things that must be done and prepared to get a business license service.

\section{Management Requirements}

The requirements for obtaining a business license that must be fulfilled or prepared by the applicant are also an inseparable part to see the extent of the ease of procedures in obtaining a business permit organized by the Makassar City BPTPM. The management of a business license must attach the following requirements: (a) Application letter addressed to the Head of Makassar City BPTPM, (b) 1 copy of the identity card of the owner/person in charge of the company to verify the identity of the owner or person in charge of the company . (c) 1 copy of the Company Establishment Deed from the applicant, (d) 1 copy of the NPWP from the applicant to find out that the company has paid taxes, (e) Recommendations from the Head of the Environment, Lurah/Village Head and local Camat, and (f) 2 (two) pieces of $3 \times 4$ size photographs that will be attached to the business license and 1 more sheet as an archive in the office.

For the processing of a business license, it must start from taking the form of a business license application letter, then a certificate signed by the Head of the Environment, Lurah/Village Head and the local Camat. After the application letter and certificate have been signed and filled with correct and complete data, then the BPTPM will conduct a review of the requested location. After all the requirements are met, a business license is issued.

\section{Procedure Stages and Mechanisms}

After the public knows and understands clearly the procedures and requirements for managing a business license, what is no less important is the stages of the procedure in order to determine whether or not the management is fast or slow. A convoluted process is not a guarantee that the procedure is said to be regular and it is also inappropriate to assume that it is a rule that can guarantee order. Regularity in the procedure format is a form of harmony that synergizes with each other in a simplicity format including the stages of service.

The stages of the procedure for obtaining a business license that have been determined at the Makassar City BPTPM start from the applicant visiting the Makassar City BPTPM office. The community as an applicant goes to the Makassar City BPTPM office and receives information/explanation from the licensing staff regarding the procedures and requirements that must be prepared and fills out a business permit application form provided by the Makassar City BPTPM apparatus.

After all the requirements are met, the applicant submits the completed application form along with the requirements to the Makassar City BPTPM apparatus and shows the requirements for obtaining a business license. When all the requirements for obtaining a business license are 
complete, the Makassar City BPTPM apparatus submits an application for a business license to the Makassar City BPTPM Head to be approved for distribution to the applicant/community.

\section{Service Rates}

As a consequence of services related to the implementation of the granting of business licenses, the government has set a service fee rate for service users, in this case the applicant, which has been stipulated in a Regional Regulation.

The service tariff/cost referred to in this study is the fee that has been determined based on the Regional Regulation and the applicant's affordability of the predetermined tariff/fee. Management fees are detailed with the following conditions: (a) Management Fees, it is generally known that in the management of a permit application, whatever its form, it is inseparable from the tariffs/fees that often receive comments or spotlight from the public as a result of sometimes more costs that must be incurred than what has been paid for. set. Under the pretext of administrative costs that provide an opportunity for unscrupulous officers to legalize banking levies which tend to cause problems with the smooth running of an affair. (b) Service Time, A service can be said to be good if the service requires fast and or on time. Therefore, the services provided must pay attention to time which is one of the standards of good service. Service time in this study is defined as the period of service delivery from submitting an application/request entry to the stage of completion of a business license (can be taken by the applicant). (c) Clarity of Application Completion Time. The clarity of the completion time of the application for a certain permit depends on the discipline of the apparatus in carrying out its work. This means whether the apparatus can complete the permit on time according to service standards. The standard time for processing business licenses has been set for a maximum of 12 working days. Licensing services that are overdue (12 working days) are a criterion for poor service and the number of complaints from permit applicants, if the processing of these permits tends to take a long time.

\section{Service Time Continuity}

In the service of service activities, sometimes it is found halting or intermittent due to the termination of service activities by officers. This can be caused by officers carrying out other activities outside of licensing service activities, whether it is due to a break time or other things that cause services to stop. However, this can be unreasonable when officers are not disciplined in using rest periods such as increasing rest hours.

The continuity of service time is a condition where the officer does not stop the service activities provided to the community in other words that the service will continue to be carried out so that the working hours / service time are over. A service activity can be stopped due to a period of rest and this is a situation that we often encounter in all government agencies.

Makassar City BPTPM in providing business license services provides 7 (seven) working hours per day to serve the community. In a service condition like this, it is possible for service delays to occur which can be caused by one thing or another.

\section{Officer Behavior and Abilities}

The behavior and ability of each person in providing services is certainly different. Behavior is reflected when accepting authority and responsibility is responded to actively or passively. Behavior and ability are one of the determinants of the success of a task, authority and responsibility.

The application of public service rules is strongly influenced by the behavior and ability of officers to achieve work success (Skorková, 2016). The success of a job is largely determined by the quality of services provided as a mirror of behavior and abilities, thus affecting openness

Copyright $\odot$ 2021, Journal of Asian Multicultural Research for Social Sciences Study, Under the license CC BY-SA 4.0 
between officers and the public as users. (a) Officer Behavior. Good service delivery is also influenced by the behavior of service providers. Understanding the behavioral context here concerns the behavior of officers in providing services wholeheartedly and removing obstacles that may occur when providing services. The assessment of the officers here is directed at creating openness and satisfaction for those who manage business permits at the Makassar City BPTPM. and (b) Officer Knowledge. The knowledge possessed by officers here can be interpreted as the ability to think, understand and at the same time be able to apply it in written and oral form which of course can be understood by others. This knowledge is very important to provide explanations and understanding to respondents in processing business license applications. In all forms of community service activities, people are usually curious about various things regarding the public services they want, for example the requirements that must be prepared in managing a business license, the costs required, service procedures, the problem of completion time for business license services and so on. If officers do not have sufficient knowledge and broad insight in carrying out their daily tasks, the user community will certainly be disappointed which can result in distrust of the quality of services provided. Therefore, every officer must have a complex knowledge in carrying out their duties starting from the ability to think, understand and provide easy solutions to any problems that may arise.

\section{Timely System in Business License Service}

Yusuf (Rahmayanty, 2010) said that a business license is a preventive juridical government instrument, which is used as a means of administrative law to control people's behavior. Meanwhile, according to Bash (Rahmayanty, 2010) a business license is a legal act of state administration that produces regulations based on the requirements and procedures as stipulated by the provisions of the applicable laws and regulations.

The affirmation of the urgency of e-Government is also supported by the Presidential Instruction of the Republic of Indonesia No. 3 of 2003 concerning the National Policy and Strategy for the Development of e-Government and the Minister of Communication and Informatics No. 126/M/KI/K/VI/2002 concerning Circular on Website Utilization as a form of the government's seriousness in utilizing technology. information and communication in the government process.

Licensing services can be defined as all forms of services which in principle are the responsibility and are carried out by Government Agencies at the Center, in the Regions, both in the context of efforts to meet the needs of the community and in the context of implementing the provisions of laws and regulations, the form of the service product is permits or licenses. script.

Because reliability is one aspect of the integrated licensing service variable in this study, it can be stated that in terms of reliability, the integrated licensing service at BPTPM Makassar City is quite good.

This is in accordance with the opinion of Silalahi (2003) which reveals that: The services provided by the state apparatus are still in the present and accounted level, meaning that organizations or bureaucrats are aware of and know about their position to provide quality services, but for efforts to achieve on the quality of service has not been serious to be implemented.

The above conditions are in accordance with Simbolon's (2015) statement that the orientation of organizational elements, from the leadership of the bureaucracy to the staff is mobilized to meet the interests of the community and its management is influenced by the market, so that in this case, the community is placed in the top position and the bureaucratic leadership in the lowest position. Contrary to the previous principle, bureaucratic leaders are in the highest 
position with the community at the lowest position, so that the orientation of the organization's services to leaders and management influences the market.

Moreover, officers who have a high sense of empathy are part of the service process that should be. Miharja et al (2021) say that service starts from a sense of caring. Service should be given with all pleasure and with a pleasant face. It is even said that with the attitude and concern of the government in serving, it will give rise to public respect for the government.

This is in accordance with the opinion of Febrianda, (2009) which reveals that: The services provided by the state apparatus are still in the present and accounted level, meaning that organizations or bureaucrats are aware of and know about their position to provide quality services, but for efforts in a positive direction. until the quality of service has not been serious to be implemented.

Business content services are services provided to the general public who want to carry out business activities. This understanding confirms that basically licensing services are a process of interaction between the party providing the service (the government) and the party providing the service (the community). In this study, the aspects used to obtain an overview of public services at the Makassar City Integrated Licensing and Investment Agency (BPTPM) are tangibles, reliability, responsiveness, assurance and empathy. empathy).

\section{Tangible}

The first aspect of measuring integrated licensing services in this study is the tangible aspect. Tangible here is defined as the physical form of every facility and infrastructure that supports the level of service provided to the community. These physical facilities are the first seen by the community and play a major role in realizing a high level of public service.

The tangible aspects measured in this study are the appearance of bureaucrats in providing services, the readiness of complete work facilities to support the implementation of the work, and the comfort of the space used in the service.

Tangible is one aspect of the integrated licensing service variable in this study. Therefore, it can be stated that from a tangible aspect, the integrated licensing service at the Makassar City BPTPM is quite good. This description is in accordance with the opinion of Rahmayanty (2010) which states that community needs include practical needs and emotional needs. Practical needs include perceived values in tangible forms including instruments, tools and facilities that can be touched and seen, while emotional needs include physiological sense values that are fulfilled from the attitudes, actions and behavior of service personnel. Therefore, for the business of building and strengthening relations with the community, the efforts of service officers are required to be efficient and effective, find the right community, serve them well to achieve a loyal community.

This condition proves that the public service support facilities in this agency still need attention from the leadership and decision makers in the Makassar City BPTPM environment. Likewise, based on the observations of researchers, the need for facilities and infrastructure has not been met in accordance with the standards required for integrated services including: (1) adequate office buildings, (2) service rooms that meet service standards, tables and chairs (3) computer facilities as needed, (4) filing cabinets to support archival documents and data bases, and (5) other supporting facilities such as official vehicles, generators, air conditioners, photocopiers, and internet networks.

Therefore, with regard to the readiness of the completeness of supporting facilities for the implementation of work and the comfort of the space used in licensing services, it is appropriate for the city government to provide new buildings that can support the implementation of 
integrated service tasks, such as integrated service buildings that have been known to the public such as service buildings in Makassar City BPTPM As far as the researcher's knowledge, since the establishment of Makassar City BPTPM, it has not had its own building, and this office has moved 3 times to use a building owned by the Makassar City BPTPM business permit which is not being used. The office building currently occupied is the Makassar City BPTPM building which is no longer occupied by other agencies. Such conditions will clearly make it difficult to carry out service tasks.

\section{Reliability}

Reliability is closely related to the ability of existing human resources to fulfill services in accordance with applicable regulations or standards. To measure the reliability aspect in this study, four indicators were used, namely the readiness of bureaucrats in place or in the workspace when needed, the speed of the service process provided by bureaucrats, the ability of bureaucrats to meet community needs, the suitability of services provided by bureaucrats with existing procedures.

Reliability is one aspect of the predictor of business content services in this study (Ferrero et al., 2019). Therefore, it can be stated that in terms of reliability, the integrated licensing service at the Makassar City BPTPM is quite good. In order for the service to be satisfactory to another person or group of people being served, the perpetrator in this case the officer, must be able to meet 4 main requirements, namely: (1) polite behavior, (2) how to convey something related to what should be done. received by the person concerned, (3) the right time to deliver, and (4) hospitality.

From the analysis of the data above, it appears that the four predictors from the aspect of reliability provide relatively equal contributions to this aspect in the good category. One thing that needs attention is the predictor of the speed of the service process provided by bureaucrats.

The results of observations made in the field indicate the fact that in recent developments to facilitate licensing services, the Makassar City government in this case the Makassar City BPTPM based on the Makassar Mayor Regulation only requires a grace period of 3 hours to process a business license until the permit is issued and accepted. by the applicant. However, based on the information obtained by the researcher, it is possible to issue a business license within 3 hours provided that all administrative requirements can be met by the community as the permit applicant. It is different when the administrative requirements are stated to be lacking, then the Makassar City BPTPM is not willing to accept the file, and the permit cannot be issued within 3 hours.

The administrative requirements referred to must be met, for example, to apply for a business license, including; (1) Written application; (2) Identity card, (3) Proof of payment of PBB in progress, (4) Deed of business, (5) passport photo, (6) Stamp of Rp.6,000. (six thousand rupiah) as many as 3 pieces.

\section{Responsiveness}

Responsiveness is given directly when there is an interaction between bureaucrats and the public. This responsiveness is very important because even agency management cannot do much when the moment of truth occurs. This is the process of shaping the performance of public services when the service process is in progress. To measure the responsiveness aspect in this study, four indicators were used as set out in the operational definition, namely the ability of bureaucrats to be responsive in dealing with problems that arise, the readiness of bureaucrats to provide clear and easy-to-understand information, bureaucratic actions to 
immediately accelerate the application process from all parties. parties, prioritizing the interests of service to the community.

This condition is in accordance with the statement that the existence of a government is for the people/society. Therefore, the real community of public organizations (government) is the community. Simbolon (2015) argues that in the public sector, the government service community is always located as a citizen who in fact is the head of the government, so it is natural for the community to get the best service from the government.

Observations made by researchers in the field also clearly show that if the people who come have an interest in obtaining permits, then the information section is directed to obtain services from the apparatus in charge of the licensing unit in question. The number of officers specifically assigned to this unit is two people. Another thing is that if in the licensing process there are obstacles faced by the applicant, then at that time the authorities immediately provide a response to find the best solution for the problems faced by the applicant. However, if the apparatus as a servant has not been able to provide a solution, then the head of the service section immediately handles the problems encountered.

Responsiveness is one aspect of the integrated licensing service variable in this study. Therefore, it can be stated that from the aspect of responsiveness, the integrated licensing service at the Makassar City BPTPM is quite good.

From the data analysis, it appears that the four predictors from the responsiveness aspect gave relatively the same contribution to this aspect in the good category. Predictors that need to be considered are predictors that prioritize the interests of service to the community.

\section{Guarantee}

When interacting with government bureaucrats, it is only natural that people consider the risks that will occur. This assurance aspect is a tool to minimize the risks that may arise during the interaction. This aspect will make people want to come back with service providers.

To measure the assurance aspect in this study, four predictors were used as described in the focus description and research focus indicators, namely the accuracy of bureaucrats when providing services according to agreed promises, the ability to create a sense of security and comfort when serving, certainty and clarity regarding time and service fees, and ease of contacting bureaucrats in charge of service.

If confirmed with the existing assessment criteria interval scale, the percentage score of respondents' answers to the six predictors from the assurance aspect are all in the good category. This means that the predictors of the accuracy of bureaucrats when providing services according to agreed promises, the ability to create a sense of security and comfort when serving, certainty and clarity regarding the time and cost of services, and ease of contacting bureaucrats who are authorized in service, are classified as good. Judging from the accuracy of bureaucrats when providing services according to agreed promises, the ability to create a sense of security and comfort when serving, certainty and clarity regarding the time and cost of services, and the ease of contacting bureaucrats who are authorized in service, the aspect of guaranteeing the apparatus at the Makassar City BPTPM is quite good.

Relevant to the results of this research, Sudarsono (1998) suggests that the function of the government is not only to carry out service activities but also to ensure that the services provided are oriented to the interests of the community. It can also be stated that the management orientation of a public service organization must really pay attention to the aspirations of the community as its people and place their interests as the first interest that must be served. 
The results of the researcher's observations at the research locus that the determination of administrative costs for business management has been determined according to the Regional Regulation and according to the classification of the type of business and the size of the business capital owned by the applicant. Business licenses have a retribution rate according to Regional Regulation No. 12 of 2003 concerning Levies for Business Place Permits and Regional Regulation No. 21 of 2001 concerning Licensing Retribution in the Trade and Investment Industry Sector. In addition, the information obtained by researchers in the field that the lowest amount of administrative costs is Rp. 50,000 (fifty thousand rupiah) and the highest fee is Rp. 750,000 (seven hundred and fifty thousand rupiah).

\section{Empathy}

Empathy means feeling what people feel. Empathy makes the community, in this case the community feel part of the service itself. In line with this, based on the explanation of Ndraha (2005), it can be said that for public services, the government functions as a maker, seller and distributor, while the people are the buyer, buyer, recipient of government products. The relationship between the government and the governed in this situation is likened to the relationship between producers and society and is called transactional or transformational relations.

To measure the aspect of empathy in this study, 3 (three) indicators were used as previously determined, namely Attitude of attention in handling complaints faced by service applicants, being fair in providing services to all parties, and polite attitude given by bureaucrats when providing services. service.

If confirmed, the six indicators from the aspect of empathy are all in the good category. This means that the indicators of attentiveness in handling complaints faced by service applicants, being fair in providing services to all parties, and the polite attitude given by bureaucrats when providing services, are classified as good. Judging from the attitude of concern in handling the complaints faced by service applicants, being fair in providing services to all parties, and the polite attitude given by bureaucrats when providing services, the empathy aspect of the apparatus at the Makassar City BPTPM is quite good.

With regard to the description, Sinambela (2008) revealed that quality services can also be carried out with the concept of "wholehearted service" as the motto of Makassar City BPTPM. Patricia Patton's wholehearted service is meant to be service that comes from oneself that reflects emotions, character, beliefs, values, points of view, and feelings. Therefore, the service apparatus is required to provide services to the recipients of public services wholeheartedly. This kind of service is reflected in the sincerity of the apparatus to serve. Seriously, the service apparatus makes community satisfaction its main goal.

Empathy is one aspect of the integrated licensing service variable in this study. Therefore, it can be stated that in terms of empathy, the integrated licensing service at the Makassar City BPTPM is quite good.

The analysis of the data above shows that the three predictors from the aspect of empathy make a relatively equal contribution to this aspect. The highest value is found in the predictor of attentiveness in handling complaints faced by applicants. While the lowest value was obtained as a predictor of politeness given by bureaucrats when providing services. This means that there are still a small number of bureaucrats who are not polite when providing services. As observed by researchers in this office, there are still male bureaucrats who serve the community while smoking, there is also the attitude of service officers when they are processing public files. who is busy reading and sending short SMS messages via his cellphone in front of the public. 
This empirical fact is certainly not in accordance with the current apparatus' paradigm of service. The development of the apparatus, including the attitude of service, needs to be carried out intensively and requires special attention from the leadership, considering this is a problem that cannot be ignored.

From the results of the analysis of the overall predictors studied, it appears that the predictor of competence of the apparatus is in the good category, but from all aspects of the competence of the apparatus the lowest predictor value is the relevance of the skills mastered to the field of work of the apparatus. This shows that the competence of the apparatus in licensing services in the city of Makassar still needs to be improved.

The predictor of apparatus commitment is in the good category, but there is still a predictor that has the lowest rating on the aspect of apparatus commitment, namely having high loyalty to the agency. This shows that the higher the commitment of the apparatus, the better the integrated licensing service in the city of Makassar.

\section{Conclusion}

The strategy of implementing bureaucratic ethics in providing business license services in Makassar City with the results showing that the registration of business licenses with the online system is considered adequate and in terms of quality it is concluded that it is inadequate for the licensing service process, the implementation of the queuing system in business license services is a gap with what is programmed by the government. with what the community expects, and on time service in the business license service, no apparatus has shown adequate performance.

\section{References}

Al Hasani, A. (2018). Pengaruh implementasi kebijakan teknologi administrasi terhadap kinerja aparatur Kecamatan Ujungberung Kota Bandung (Doctoral dissertation, UIN Sunan Gunung Djati Bandung).

Anwaruddin, A. (2004). Pasang Surut Paradigma Administrasi Publik. Jurnal Ilmu Administrasi: Media Pengembangan Ilmu dan Praktek Administrasi, 1(2), 1-16.

Deshapriya, G. W. N. T., Dharanidu, G. H. G. M., \& Jayakody, J. A. R. T. (2017). Framework for Data Management in Public Service Delivery Applications in Sri Lanka Using Blockchain Technology (Doctoral dissertation).

Dwiyanto, A. (2006). Mewujudkan Good Governance Melalui Pelayanan Publik. Yogyakarta : Gajah Mada Press

Edward III, G. C. (1980). Implementing public policy. Congressional Quarterly Press.

Febrianda, L. (2009). Rekonstruksi regulasi pelayanan kependudukan dan pencatatan sipil oleh birokrasi pemerintahan dalam perspektif hukum administrasi negara (Doctoral dissertation, UNIVERSITAS DIPONEGORO).

Ferrero Bermejo, J., Gomez Fernandez, J. F., Olivencia Polo, F., \& Crespo Marquez, A. (2019). A review of the use of artificial neural network models for energy and reliability prediction. A study of the solar PV, hydraulic and wind energy sources. Applied Sciences, 9(9), 1844.

Haq Muis, M. A. (2016). Analisis Implementasi Good Governance Dalam Pelayanan Publik Di Kecamatan Panakkukang Kota Makassar (Doctoral dissertation).

Keyton, J. (2017). Communication in organizations. Annual Review of Organizational Psychology and Organizational Behavior, 4, 501-526. 
Li, G., Hou, Y., \& Wu, A. (2017). Fourth Industrial Revolution: technological drivers, impacts and coping methods. Chinese Geographical Science, 27(4), 626-637.

Maani, K. D. (2010). Etika pelayanan publik. Jurnal Demokrasi, 9(1).

Miharja, M., Salim, E., Nachrawi, G., Putranto, R. D., \& Hendrawan, A. (2021). Implementation of Emergency Public Activity Restrictions (PPKM) in Accordance With Human Rights and Pancasila Principles. Budapest International Research and Critics Institute (BIRCI-Journal): Humanities and Social Sciences, 4(3), 6855-6866.

Myers, S. A. (2002). Perceived aggressive instructor communication and student state motivation, learning, and satisfaction. Communication Reports, 15(2), 113-121.

Ndraha, T. (2005). Teori budaya organisasi. Jakarta: Rineka Cipta.

Rahmayanty, N. (2010). Manajemen pelayanan prima. Yogyakarta: graha ilmu, 89.

Rose, R. (2015). 3. England: The Traditionally Modern Political Culture. In Political culture and political development (pp. 83-129). Princeton University Press.

Said, E. W. (2007). Power, politics, and culture. Vintage.

Silalahi, D. (2003, July). Pembangunan Berkelanjutan dalam Pengelolaan Sumber Daya Alam yang Berbasis Pembangunan Sosial dan Ekonomi. In Makalah Bahasan pada Seminar dan Lokakarya Pembangunan Hukum Nasional VIII Badan Pembinaan Hukum Nasional Departemen Kehakiman dan HAM, Denpasar, Bali (pp. 14-18).

Simbolon, M. (2015). Hubungan Sistem Informasi, Kompetensi Teknis Dan Budaya Organisasi Dengan Prestasi Kerja Di Baranahan Kemhan RI (Doctoral dissertation, Universitas Pembangunan Nasional Veteran Jakarta).

Sinambela, L. P. (2008). Reformasi pelayanan publik. library.stik-ptik.ac.id

Skorková, Z. (2016). Competency models in public sector. Procedia-Social and Behavioral Sciences, 230, 226-234.

Sudarsono, S. (1998). Penetapan Sasaran Kesempatan Kerja dan Produktivitas Tenaga Kerja. Journal of Indonesian Economy and Business, 4(1), 1-20.

Ugor, P., \& Mawuko-Yevugah, L. (2016). Information and Communication Technologies and African Youth in a Globalized World. In African Youth Cultures in a Globalized World (pp. 145-166). Routledge.

Wahab, S. A. (2021). Analisis kebijakan: dari formulasi ke penyusunan model-model implementasi kebijakan publik. Bumi Aksara 